\title{
Magnesium supplementation in swine finishing stage: performance, carcass characteristics and meat quality
}

\section{Suplementação com magnésio na fase de terminação de suínos: desempenho, características de carcaça e qualidade de carne}

\author{
Marina Avena Tarsitano ${ }^{1 *}$; Ana Maria Bridi²; Caio Abércio da Silva ${ }^{2}$; \\ Camila Constantino ${ }^{1}$; Nayara Andreo ${ }^{3}$; Danyel Bueno Dalto ${ }^{1}$
}

\begin{abstract}
There was evaluated the performance, carcass characteristics and meat quality parameters of swine on the finishing stage receiving a dietetic supplementation with magnesium oxide $(\mathrm{MgO})$. The animals were 48 male swine, supplemented 7 days before the slaughter by the following treatments: feed with $0 ; 0.2 ; 0.4 \mathrm{e} 0.6 \%$ of $\mathrm{MgO}$ inclusion. The pigs were blocked by the initial weight as: lights, medium and heavy. The treatments had influence on the daily weight gain showing a quadratic effect, maximum inclusion point $0.3 \% \mathrm{MgO}$. The effect on the plasmatic cortisol and on the carcass yield was a linear decreasing regression. Back fat thickness shows a quadratic effect, minimal deposition point $0.37 \%$ $\mathrm{MgO}$. Amount of meat in chilled carcass, meat yield and gratification index showed quadratic effect for the treatments, the maximum points are $0.31,0.37$ and $0.28 \%$ of inclusion respectively. Water losses and liquid losses on defrosting presented quadratic effect; the minimal point was to 0.31 and $0.35 \%$ of inclusion, respectively.
\end{abstract}

Key words: Back fat thickness, carcass yield, meat color, stress

\section{Resumo}

O objetivo deste experimento foi avaliar o efeito da inclusão de óxido de magnésio $(\mathrm{MgO})$ na fase de terminação sobre o desempenho, as características de carcaça e qualidade de carne de suínos. Foram utilizados 48 suínos, suplementados com $\mathrm{MgO}$ por 7 dias antes do abate, sendo os tratamentos: rações com $0 ; 0,2 ; 0,4$ e $0,6 \%$ de inclusão de $\mathrm{MgO}$. O delineamento experimental foi em blocos casualizados, sendo os animais blocados de acordo com o peso inicial em leves, médios e pesados. O ganho diário em peso foi influenciado pelos tratamentos, apresentando efeito quadrático com ponto de máxima inclusão de $0,3 \%$ de $\mathrm{MgO}$. A suplementação com $\mathrm{MgO}$ diminuiu as concentrações séricas de cortisol, apresentando efeito de regressão linear decrescente. A espessura de toucinho apresentou efeito de regressão quadrática, em que o ponto de mínima deposição ocorreu com a inclusão de $0,37 \%$ de $\mathrm{MgO}$. Quantidade de carne na carcaça resfriada, rendimento de carne na carcaça e índice de bonificação apresentaram efeito quadrático para suplementação dietética com $\mathrm{MgO}$ sendo os pontos de máxima 0,31 , 0,37 e $0,28 \%$ respectivamente. A porcentagem de perda de água e a perda de água no descongelamento apresentaram efeito quadrático, com pontos de mínima perda iguais a 0,31 e $0,35 \%$, respectivamente.

Palavras-chave: Cor, espessura de toucinho, estresse, rendimento de carcaça

\footnotetext{
${ }^{1}$ Discentes de Doutorado do Programa de Pós-Graduação em Ciência Animal, Universidade Estadual de Londrina, UEL, Londrina, PR, Brasil. E-mail: marina_avena@yahoo.com.br; caconstantino@hotmail.com; danyelbd@hormail.com

${ }^{2}$ Profs. Drs. do Dept ${ }^{\circ}$ de Zootecnia, UEL, Londrina, PR, Brasil.E-mail: ambridi@uel.br; casilva@uel.br

${ }^{3}$ Discente de Mestrado do Programa de Pós-Graduação em Ciência Animal, UEL, Londrina, PR, Brasil. E-mail: nayarandreo@, hotmail.com

* Author for correspondence
} 


\section{Introduction}

The magnesium is the second more abundant cation on intracellular environment, the fourth more concentrated in the human body and a co factor necessary for vital enzymatic reactions in different metabolic pathways, including the glycolytic pathway. This element act on the modulation for the neuromuscular activity and act in the autonomic cardiac control (HEATON, 1973).

This mineral decreases the neuromuscular stimulation by antagonism to the calcium, reducing the acetylcholine secretion on neuromuscular junctions and as consequence reducing the muscular excitation. The diet supplementation with magnesium reduce the plasmatic concentration of cortisol and catecholamines (epinephrine and norepinephrine), decreasing the effect of the preslaughter stress (D'SOUZA et al., 1998). After the reduction in the catecholamines liberation, the muscular glycolysis is reduced and the consequence is the improvement on the meat quality. The reason for this improvement is that the smaller speed of post mortem glycolysis allows a $\mathrm{pH}$ adequate and as consequence a better water retention capacity and color for the meat (D'SOUZA et al., 1998; SCHAEFER et al., 1993).

However, the ideal period for supplementation, the magnesium source and the supplementation level that allow maximization in the meat quality parameters were not established (HAMILTON et al., 2003).

This study has the objective of evaluate the effect of the dietetic magnesium supplementation for swine, seven days before the slaughter, in the performance and meat quality.

\section{Material and Methods}

The experiment was conducted at the Farm
School of the Universidade Estadual de Londrina. The experimental animals were 48 male swine (Landrace $x$ Large White), the starter body weight were $99.91 \pm 7.47 \mathrm{~kg}$. The animals were housed in pens with compact floor of $3 \mathrm{~m}^{2}$, with two animals in each pen.

The experimental design was four treatments in randomized blocks. The animals were blocked by body weight in light $(88.68 \mathrm{~kg})$, medium $(97.8 \mathrm{~kg})$ and heavy $(106.0 \mathrm{~kg})$. The performance trial included the pen as experimental unity (six repetitions by treatments) and the carcass and meat quality evaluations included the animal as the experimental unity (twelve repetitions by treatments).

The animal feed was formulated to attend the minimal requirements established on the NRC (1998) for the swine finishing stage; there was the same nutrient composition for all the treatments (Table 1) except in the magnesium level. The premix was formulated without antioxidant ingredients as vitamin E, magnesium and selenium.

There was established an adaptation period of 10 days before the trial when all the animals received the same control feed. The trial period lasted seven days and during this time the animals were under four treatments: control feed (without $\mathrm{MgO}$ ); $0.2 \% ; 0.4 \%$ and $0.6 \%$ of $\mathrm{MgO}$ supplementation respectively.

During the trial period the animals had feed and water ad libitum. The performance measures included body weight and feed consumption, on the first and on the last day of the period. This allowed the calculation of the daily feed consumption, daily body weight gain and feed: gain ratio. Diarrhea frequency also was evaluated during the seven days by the morning, there was verified the feces consistency in a four level scale: normal, slightly viscous, viscous and liquid. 
Table 1. Animal feed percent composition, chemical and energetic.

\begin{tabular}{|c|c|c|c|c|}
\hline Ingredients & Without $\mathrm{MgO}$ & $\mathrm{MgO} 0.2 \%$ & $\mathrm{MgO} 0.4 \%$ & $\mathrm{MgO} 0.6 \%$ \\
\hline Maize & 76.81 & 76.81 & 76.81 & 76.81 \\
\hline Soybean meal & 19.61 & 19.61 & 19.61 & 19.61 \\
\hline Vegetal oil & 0.82 & 0.82 & 0.82 & 0.82 \\
\hline Dicalcium phosphate & 0.82 & 0.82 & 0.82 & 0.82 \\
\hline Limestone & 0.59 & 0.59 & 0.59 & 0.59 \\
\hline Salt & 0.31 & 0.31 & 0.31 & 0.31 \\
\hline L-lisine & 0.25 & 0.25 & 0.25 & 0.25 \\
\hline Premix $^{1}$ & 0.10 & 0.10 & 0.10 & 0.10 \\
\hline L-treonine & 0.06 & 0.06 & 0.06 & 0.06 \\
\hline Dl-methionine & 0.04 & 0.04 & 0.04 & 0.04 \\
\hline Inert & 0.60 & 0.40 & 0.20 & - \\
\hline Magnesium oxide & - & 0.20 & 0.40 & 0.60 \\
\hline TOTAL & 100 & 100 & 100 & 100 \\
\hline \multicolumn{5}{|l|}{ Calculated } \\
\hline Calcium (\%) & 0.50 & 0.50 & 0.50 & 0.50 \\
\hline Metabolizable Energy (kcal/kg) & 3.272 & 3.272 & 3.272 & 3.272 \\
\hline $\mathrm{P}$ available $(\%)$ & 0.25 & 0.25 & 0.25 & 0.25 \\
\hline Digestible Lysine (\%) & 0.83 & 0.83 & 0.83 & 0.83 \\
\hline Met + cys $(\%)$ & 0.51 & 0.51 & 0.51 & 0.51 \\
\hline Digestible Methionine (\%) & 0.27 & 0.27 & 0.27 & 0.27 \\
\hline Crude Protein (\%) & 15.53 & 15.53 & 15.53 & 15.53 \\
\hline Magnesium mg $/ \mathrm{kg}^{2}$ & 1580 & 3439 & 5101 & 5638 \\
\hline
\end{tabular}

${ }^{1}$ Vitamin A=3.500.000 UI; B1=600mg; K3=3000mg; Copper=8000mg; Folic Acid=1000mg; D3=650000UI; Biotin=30mg; Iodine=1000mg; Fe=60000mg; Zinc=100000mg; B6=1000mg; B2=3500mg; Niacin=20000mg; Manganese=25000mg; Pantotenic Acid $=10000 \mathrm{mg} ; \mathrm{B} 12=18000 \mathrm{mg}$.

${ }^{2}$ Analysis realized on experimental feed to measure Mg level.

Source: Elaboration of the authors.

The swine was slaughter having average body weight of $109.12 \pm 7.0 \mathrm{~kg}$ in a commercial slaughter house $35 \mathrm{~km}$ away from Londrina, Paraná. The pre-slaughter handling consisted on the feed withdrawal twelve hours before the shipment; the animals remained in liquid diet until the slaughter. The total time under fasting was fifteen hours. The shipment was around 6:00am on the farm and the transportation time until the slaughterhouse was around one hour.

The slaughter was preceded by electric stunning, according to the Humanitarian Slaughter Standards (BRASIL, 2000), there was used a Petrovina ${ }^{\circledR}$ IS 2000 device with two electrodes (350Volts and 1.3 A during 3 seconds). The bleeding was realized by the big vessels section with the animals on the vertical position suspended by the posterior member. After the bleeding was realized the scalding and evisceration, the carcasses were divided halved longitudinally and cooled to the temperature of $2 \pm 1^{\circ} \mathrm{C}$, during 24 hours, on cooling chamber.

To evaluate the physiologic stress were collected three blood samples of $5 \mathrm{~mL}$ for each animal on the bleeding gutter. One sample had fluoride as anticoagulant to the lactate analysis and the other two had no anticoagulant to the magnesium and cortisol analysis. The lactate analysis was realized by the enzymatic-UV method, the magnesium and cortisol were measured on the serum by xilidil blue method and chemiluminescence, respectively.

After a 24 hours period, the carcasses were evaluated individually according the orientation of 
Brazilian Association of Swine Breeders (ABCS, 1986). The carcasses were weight after the slaughter (hot carcass weight) and after 24 hours of cooling (chilled carcass weight). The weight loss during the cooling process was calculated having as parameter the hot and the cold carcass weight. The carcass yield was calculated taking in account the relation between the hot carcass weight and the live weight from the animal.

The meat's pH was measured on the longissimus dorsi muscle, close to the last rib in two different moments. The first measure occurs 45 minutes after the slaughter (initial $\mathrm{pH}$ ) and the second measure was taken after 24 hours of cooling (final $\mathrm{pH}$ ), there was used a portable insertion device with insertion electrodes Testo 205.

After the cooling time of 24 hours the left half carcasses were sectioned between the two last ribs to measure the loin eye area, longissimus dorsi depth and back fat thickness. These three measures were realized on the same place, around $6 \mathrm{~cm}$ away from the mid line. Having as start point the back fat thickness value and the longissimus dorsi depth value, there was estimated the carcass meat yield (CMY) and the carcass amount of meat (CAM), following the methodology from Guidoni (2000). The calculated gratification index (GI), was express as percentage and represented an increase factor to the value pay per $\mathrm{kg}$ of slaughter swine considering the CMY and the hot carcass weight (HCW), this index was described by Fávero, Guidoni and Belaver (1997):

$$
\mathrm{GI}=37,004721+0,094412 \times \mathrm{HCW}+1,144822 \mathrm{x}
$$
CMY - 0,000053067 x HCW x CMY + 0,000018336 x HCW $2+0,000409$ x CMY 2.

After 24 hours from the slaughter, there was removed from each left half carcass one sample from the longissimus dorsi muscle. The samples were identified, packed and accommodated in thermal containers for transportation and posterior analysis.

The muscle was divided in six different samples, from tail to head way: color analysis, marbling and water losses; the second was for sensorial analysis; the third was for water losses during the defrosting process, the cooking process and shear force; the fourth was for lipid oxidation; the fifth was for the myofibrillar fragmentation index and the last was for the total lipid analysis. All the samples, except the first that was analyzed on the same day, were individually vacuum packed and frozen to posterior analysis.

The color was analyzed after $30 \mathrm{~min}$ of oxygen exposure, this allow the reaction between myoglobin and the oxygen in the atmosphere, with the portable colorimetric device Minolta CR10 to evaluation from the $\mathrm{L}^{*}$ (luminosity), $\mathrm{a}^{*}$ (red-green intensity) and $b^{*}$ (yellow-blue intensity) in the CIELAB system (MINOLTA, 1998). The $\mathrm{a}^{*}$ and $b^{*}$ value were used to calculated the croma and the hue value, the color in each sample was measured in three distinct points.

The marbling score was subjectively evaluated using photographic standards (AMERICAN MEAT SCIENCE ASSOCIATION, 2001) were assigned grades from 1 to 5 ( $1=$ marbling signs and $5=$ abundant marbling)

The percentage of water losses was realized by the technique described by Barbut (1996) there was weight a $2 \mathrm{~g}$ sample in semi analytic balance, the sample was placed between two filter papers and pressed by two acrylic plates with around $10 \mathrm{~kg}$ weight during 5 minutes. After the pressing time, the sample was weight again in order to calculate the water losses.

The sensorial analysis was realized by a panel with ten trained tasters. There was used a structured scale from 1 to 9 points (1 extremely acceptable and 9 extremely unacceptable) for the parameter sample's overall acceptability; for odor and juiciness the scale was from 1 to 5 (odor: 1 extremely intense and 5 none; juiciness: 1 none and 5 high juiciness); for the tenderness the scale was from 1 to 7 (1 very tough meat and 7 very tender meat). The samples 
were prepared in preheated oven $\left(180{ }^{\circ} \mathrm{C}\right)$ and coked until the point to have an internal temperature of $72{ }^{\circ} \mathrm{C}$. The tasters received for the evaluation two samples, one that no receive the $\mathrm{MgO}$ and another from the treatment with inclusion of $0.6 \%$ of $\mathrm{MgO}$ (ABNT, 1993).

To realize the tenderness evaluation, the samples passed first for the evaluation of liquid losses on defrosting and cooking process. The samples were weight, frozen and weight again after 24 hours of defrosting, to evaluate the liquid losses by defrosting. After this process, the same samples were coked in electric oven, preheated to $180{ }^{\circ} \mathrm{C}$ until the point to have an internal temperature of 72 ${ }^{\circ} \mathrm{C}$. Following this process the samples were weight again to measure the liquid losses during the coking and stored during 24 hours in a temperature $4 \pm 2^{\circ} \mathrm{C}$ (BRIDI; SILVA, 2009). The follow step was divided each sample in six cylindrical sub samples with around $2.5 \mathrm{~cm}$ of length and $1.27 \mathrm{~cm}$ of diameter, using cylindrical steel sampler. The shear force was measured perpendicularly to the muscular fiber orientation with a Warner-Bratzler blade adapted to the texturometer Stable Mycro Systems TA-XT2i (WHIPPLE; KOOHMARAIE; DIKEMAN, 1990). The speed was $5 \mathrm{~mm} / \mathrm{s}$ in pre and posttest and $2 \mathrm{~mm} / \mathrm{s}$ during the test.

The lipid oxidation were analyzed by the methodology indicative of thiobarbituric acid reactive substances described by Tarladgis, Pearson and Dugan Junior (1964) and modified by Crackel et al. (1988). This method consist on perform spectrophotometrically on $530 \mathrm{~nm}$ the complex of red coloration compound by the condensation of two moles of acid 2 thiobarbituric (TBARS) with one mol of malonaldehyde and/or other substances that can react with TBARS.

The index of myofibrillar fragmentation (IMF) was measured by the technique described by Culler et al. (1978). In order to perform the extraction of myofibrills were used $4 \mathrm{~g}$ of muscular tissue, without fat and connective tissue; the samples were homogenized in Ultra turax with 9500rpm in $20 \mathrm{~mL}$ of buffer solution during 40 seconds. The samples were centrifuged in $3500 \mathrm{rpm}$ during $15 \mathrm{~min}$ in $2^{\circ} \mathrm{C}$ and the supernatant discarded. The precipitate was resuspended with $20 \mathrm{~mL}$ of buffer solution and the samples were again centrifuged and the supernatant discarded. The precipitate was resuspended again with $10 \mathrm{~mL}$ of buffer solution and submitted to the vortex until homogenize the sample at point that allow to be filtered in strainer with polyethylene mesh (size 18) to remove the connective tissue. At this point was added more $10 \mathrm{~mL}$ of buffer solution to wash the tube and help on the filtration process. The extraction process was made in duplicate.

The total lipid analysis was carried by the Soxhlet methodology using petroleum ether (INSTITUTO ADOLFO LUTZ, 1985).

The generate data was submitted to ANOVA with polynomials derivation using the SAEG software (UNIVERSIDADE FEDERAL DE VIÇOSA, 1997), for the variable frequency of diarrhea was realized the chi-square test and the sensorial analysis was submitted to F Test.

\section{Results and Discussion}

For the performance trial the variables daily weight gain and frequency of animals with diarrhea were significantly affected by the treatments (Table 2). There was observed a quadratic regression effect having as point of maximum daily weight gain the level of inclusion of $0.3 \%$ of $\mathrm{MgO}$ on the feed. The $\mathrm{MgO}$ appear have one effect on nutrient repartitioning reducing the fat deposition and favoring the muscular tissue deposition, allowing the increasing on daily weight gain. 
Table 2. Observed means and standard deviation for performance measures (Initial weight=IW, final weight=FW, daily feed consumption=DFC, daily body weight=DBW, feed to gain=F:G and diarrhea frequency=DF) for swine treated with magnesium supplementation during 7 days before the slaughter.

\begin{tabular}{ccccccc}
\hline $\begin{array}{c}\text { MgO inclusion on } \\
\text { feed (\%) }\end{array}$ & IW (kg) & FW (kg) & DFC (kg) & DBW (kg) & F:G & DF (\%) \\
\hline 0 & $100.0 \pm 6.86$ & $108.24 \pm 6.72$ & $3.29 \pm 0.51$ & $1.18 \pm 0.17$ & $2.82 \pm 0.42$ & 0 \\
0.2 & $99.84 \pm 6.01$ & $108.61 \pm 6.60$ & $3.41 \pm 0.21$ & $1.25 \pm 0.17$ & $2.75 \pm 0.25$ & $9.1 \mathrm{a}$ \\
0.4 & $99.97 \pm 9.34$ & $109.87 \pm 9.21$ & $3.65 \pm 0.47$ & $1.41 \pm 0.28$ & $2.61 \pm 0.28$ & $50.0 \mathrm{~b}$ \\
0.6 & $99.83 \pm 9.32$ & $109.75 \pm 7.03$ & $3.35 \pm 0.33$ & $1.36 \pm 0.14$ & $2.98 \pm 0.25$ & $88.2 \mathrm{~b}$ \\
CV (\%) & 2.29 & 2.84 & 10.38 & 14.67 & 10.80 & - \\
\hline Regression effect & NS & NS & NS & Quadratic & NS & 0.05 \\
\hline
\end{tabular}

CV - Variation Coefficient; NS - No Significant $(P>0.05) ; Y=1.150+1.34666 X-2.20833 X^{2}\left(R^{2}=0.69\right)(P<0.05)$. Different letters on the same column indicated significant differences.

Source: Elaboration of the authors.

This result is similar to that reported by Caine et al. (2000), were swine feed with diet formulated with magnesium aspartate had higher daily weight gain that swine feed a control diet. Apple et al. (2002) observed that swine feed $1.25 \%$ of magnesium mica were more efficient during the growing stage (34.0 to $68.2 \mathrm{~kg}$ of body weight) that animals feed $2.5 \%$ of magnesium mica and the control treatment (without magnesium supplementation) show intermediate results. This can be explained by the role that magnesium have on activation of several metabolic enzymes. Heaton (1973) had concluded that increasing the concentration of $\mathrm{Mg}$ inside the cell will improve the energy efficiency resulting in an improved of animal performance.

The increasing inclusion of $\mathrm{MgO}$ on diet results in diarrhea observations and as consequence reduction on daily body weight gain for the treatments with levels above $0.3 \%$ of $\mathrm{MgO}$. The $\mathrm{MgO}$ was already reported as having a laxative effect, when ingested in excessive amount, this effect is due the osmotic effect that carries the water from intracellular environment to the small intestine light. This water accumulation can produce distention and increase the peristaltic movements causing as consequence the diarrhea (FINE; SANT'ANA; FORDTRAN, 1991). According to Oliveira (2005), the magnesium intoxication can cause the reduction in consumption and a bad performance.

The results for magnesium levels, lactic acid and cortisol in the blood analysis are showed in Table 3. The magnesium and lactic acid concentration do not show any effects from the dietetic supplementation with $\mathrm{MgO}$ during the last week before the slaughter. This is similar to the observed by Apple et al. (2005) that reported no alteration on serum magnesium concentration by a dietetic supplementation with magnesium mica in animals submitted to stress by transportation. However, D'Souza et al. (1998) reported evidences that the supplementation with magnesium aspartate for swine reduce the acid lactic concentration in the muscular tissue 40 minutes before slaughter, that mean a reduced stress effect on the muscular glycogenolysis. 
Table 3. Observed means and standard deviation for seric Mg concentration, lactic acid and cortisol from swine treated with different levels of $\mathrm{MgO}$ during seven days before the slaughter.

\begin{tabular}{cccc}
\hline $\mathrm{MgO}$ inclusion on feed (\%) & Magnesium (mg/dL) & Lactic Acid (mg/dL) & Cortisol (ug/dL) \\
\hline 0 & $2.68 \pm 0.49$ & $103.20 \pm 32.16$ & $10.60 \pm 3.38$ \\
0.2 & $2.80 \pm 0.33$ & $138.71 \pm 52.31$ & $12.04 \pm 2.80$ \\
0.4 & $2.73 \pm 0.43$ & $100.64 \pm 41.45$ & $8.09 \pm 2.75$ \\
0.6 & $3.00 \pm 0.33$ & $113.50 \pm 34.22$ & $8.09 \pm 4.39$ \\
Regression effect & $\mathrm{NS}$ & $\mathrm{NS}$ & Linear \\
\hline $\mathrm{CV}(\%)$ & 14.79 & 31.46 & 35.60 \\
\hline
\end{tabular}

NS- No significant $(\mathrm{P}>0.05) ; \mathrm{Y}=11.2134-5.45461 \mathrm{x}\left(\mathrm{R}^{2}=0.72\right)(\mathrm{P}<005) ; \mathrm{CV}-$ Variation coefficient

Source: Elaboration of the authors.

There was observed a linear decreasing effect in the serum concentration of cortisol, what means that when increasing the level of $\mathrm{MgO}$ on the feed the serum level of cortisol for the animals were reduced. This result is according evidences founded in the literature that the $\mathrm{Mg}$ supplementation on the diet can reduce the pre slaughter stress by reducing the serum concentration of cortisol and catecholamines. D'Souza et al., (1998) supplementing swine feed with magnesium aspartate found lower serum concentration of noradrenaline on animals submitted to the supplemented diet that those under the control diet. In this same study, the group under the supplemented diet had lower concentrations of lactic acid in the muscle 5 and 40 minutes after the slaughter that the control animals. However 24 hours after the slaughter this difference was not present anymore.

The carcass parameters do not showed significant differences between the treatments. The exception was the carcass yield that showed a linear decreasing effect (Table 4). The carcass yield is a mathematic relation between the live weight and the carcass weight, the reduction in amount of backfat in the carcasses of animals that receive the $\mathrm{MgO}$ supplementation may have caused decrease in carcass yield. These results are different from Apple et al. (2000a) and Hamilton et al. (2002), which report no differences in carcass yield between treatments with magnesium supplementation for sheep and swine, respectively.

Table 4. Means and standard deviation observed for hot carcass weight, chilled carcass weight, carcass yield and weight losses during cooling process from swine treated with different levels of magnesium oxide $(\mathrm{MgO})$ for seven days before slaughter

\begin{tabular}{ccccc}
\hline $\begin{array}{c}\text { MgO inclusion on } \\
\text { feed }(\%)\end{array}$ & $\begin{array}{c}\text { Hot carcass weight } \\
(\mathrm{kg})\end{array}$ & $\begin{array}{c}\text { Chilled carcass } \\
\text { weight }(\mathrm{kg})\end{array}$ & Carcass yield (\%) & $\begin{array}{c}\text { Weight losses } \\
\text { cooling }(\mathrm{kg})\end{array}$ \\
\hline 0 & $82.77 \pm 6.01$ & $80.55 \pm 5.91$ & $76.48 \pm 1.46$ & $2.69 \pm 0.15$ \\
0.2 & $83.22 \pm 5.18$ & $80.98 \pm 5.05$ & $76.65 \pm 1.60$ & $2.70 \pm 0.13$ \\
0.4 & $82.48 \pm 9.07$ & $80.31 \pm 8.91$ & $74.96 \pm 2.19$ & $2.64 \pm 0.23$ \\
0.6 & $81.03 \pm 8.05$ & $78.83 \pm 7.88$ & $75.58 \pm 2.02$ & $2.72 \pm 0.16$ \\
Regression effect & $\mathrm{NS}$ & $\mathrm{NS}$ & Linear & $\mathrm{NS}$ \\
\hline CV(\%) & 5.10 & 5.12 & 2.47 & 6.15 \\
\hline
\end{tabular}

NS- No significant $(\mathrm{P}>0.05) ; \mathrm{Y}=76.5746-2.19375 \mathrm{x}\left(\mathrm{R}^{2}=0.51\right)(\mathrm{P}<0.07) ; \mathrm{CV}$ - Variation coefficient.

Source: Elaboration of the authors. 
On the Table 5 the results of muscle depth, marbling, backfat thickness and loin eye area. The back fat thickness shows a quadratic effect having the minimum point between the treatments with the inclusion of $0.37 \%$ of $\mathrm{MgO}$. This data is according to the observed by Apple et al. (2000a) that also found the reduction of back fat thickness in swine carcass when submitted to an $\mathrm{Mg}$ dietetic supplementation. These authors justified the results by the role of $\mathrm{Mg}$ on block the lipogenesis and reduce the free fatty acids available to the lipid biosynthesis.

The $\mathrm{MgO}$ supplementation do not influenced the characteristics as muscle depth and loin eye area. Authors like Schaefer et al. (1993) and Apple et al. (2000a) also do not report effects from $\mathrm{Mg}$ supplementation during short period before the slaughter on muscular characteristics from swine. The marbling score do not show any differences between treatments. This result is according with that found on the research of Hamilton et al. (2002) and Apple et al. (2000a) that report no effects from $\mathrm{Mg}$ dietetic supplementation on marbling score from swine Longissimus dorsi muscle. However on a following experiment Hamilton et al. (2003) supplying swine diets with $3.2 \mathrm{~g}$ of magnesium/day had higher marbling score that the control group. These authors report difficulties to explain the reason for this difference due the short period of supplementation (5 days).

Table 5. Measures (mean \pm standard deviation) of Longissimus dorsi (Ld) depth, loin eye area, back fat thickness and marbling score from swine treated with different levels of magnesium oxide $(\mathrm{MgO})$ for seven days before slaughter.

\begin{tabular}{ccccc}
\hline $\begin{array}{c}\text { MgO inclusion on } \\
\text { feed }(\%)\end{array}$ & $\begin{array}{c}\text { Ld depth } \\
(\mathrm{mm})\end{array}$ & $\begin{array}{c}\text { Loin eye area } \\
\left(\mathrm{cm}^{2}\right)\end{array}$ & $\begin{array}{c}\text { Back fat thickness } \\
(\mathrm{mm})\end{array}$ & Marbling score \\
\hline 0 & $60.23 \pm 5.51$ & $4.29 \pm 0.61$ & $19.73 \pm 6.84$ & $2.00 \pm 0.60$ \\
0.2 & $61.70 \pm 6.89$ & $4.43 \pm 0.62$ & $16.17 \pm 4.33$ & $2.25 \pm 0.62$ \\
0.4 & $61.27 \pm 6.65$ & $4.21 \pm 0.51$ & $16.08 \pm 4.53$ & $1.92 \pm 0.90$ \\
0.6 & $60.52 \pm 6.56$ & $4.17 \pm 0.54$ & $17.10 \pm 4.88$ & $2.08 \pm 1.00$ \\
Regression effect & $\mathrm{NS}$ & $\mathrm{NS}$ & Quadratic & $\mathrm{NS}$ \\
\hline $\mathrm{CV}(\%)$ & 9.77 & 11.66 & 24.68 & 38.73 \\
\hline
\end{tabular}

NS- No significant $(\mathrm{P}>0.05) ; \mathrm{Y}=19.6139-21.2033 \mathrm{X}+28.6875 \mathrm{x}^{2}\left(\mathrm{R}^{2}=0.97\right)(\mathrm{P}<0.06) ; \mathrm{CV}-$ Variation coefficient.

Source: Elaboration of the authors.

The amount of meat on chilled carcass, the meat yield and the gratification index has significant effects due the treatments (Table 6). The amount of meat on chilled carcass had a quadratic effect; the best yield was obtained with $0.31 \%$ of $\mathrm{MgO}$ on diet. The meat yield had a quadratic effect to the $\mathrm{MgO}$ level, the maximum point were on $0.37 \%$ of $\mathrm{MgO}$ inclusion. The increase on meat yield help to explain the differences observed on the gratification index, which also had a quadratic effect, with the maximum point calculated to $0.28 \%$ of $\mathrm{Mg}$ supplementation. The higher gratification index is explained by the increase on lean meat deposition and contributes to increase the swine carcass value on slaughterhouse, following the carcass classification procedures (FÁVERO, 2001).

The fat and muscular tissue deposition are antagonistic, this explain the fact of treatments with lower subcutaneous fat deposition were those had higher meat yield. Apple et al. (2000a) evaluating different inclusion levels of magnesium mica $(0$, 1.25 and $2.5 \%$ ) in swine diets and the influence on carcass characteristics also found a quadratic effect to the parameter percentage of meat on carcass $(49$, 20, 50, 64 and 50.09\%). 
Table 6. Measures (mean \pm standard deviation) of amount of meat on chilled carcass, meat yield on chilled carcass and gratification index from swine treated with different levels of magnesium oxide $(\mathrm{MgO})$ for seven days before slaughter.

\begin{tabular}{cccc}
\hline $\begin{array}{c}\mathrm{MgO} \text { inclusion on } \\
\text { feed (\%) }\end{array}$ & $\begin{array}{c}\text { Amount meat } \\
\text { chilled carcass }(\mathrm{kg})\end{array}$ & $\begin{array}{c}\text { Meat yield chilled } \\
\text { carcass (\%) }\end{array}$ & $\begin{array}{c}\text { Gratification } \\
\text { index (\%) }\end{array}$ \\
\hline 0 & $44.92 \pm 4.53$ & $55.91 \pm 4.98$ & $108.59 \pm 5.66$ \\
0.2 & $46.95 \pm 3.95$ & $58.48 \pm 3.31$ & $111.56 \pm 3.90$ \\
0.4 & $46.58 \pm 4.63$ & $58.52 \pm 3.20$ & $111.53 \pm 3.46$ \\
0.6 & $45.28 \pm 4.21$ & $57.79 \pm 3.31$ & $110.56 \pm 3.61$ \\
Regression effect & Quadratic $^{1}$ & Quadratic $^{2}$ & Quadratic $^{3}$ \\
\hline CV (\%) & 6.37 & 5.48 & 2.65 \\
\hline
\end{tabular}

${ }^{1} \mathrm{Y}=44.9919+12.8492 \mathrm{x}-20.8125 \mathrm{x}^{2}(\mathrm{R}=0.96)(\mathrm{P}<0.05) ;{ }^{2} \mathrm{Y}=56.0013+15.2148 \mathrm{x}-20.6406 \mathrm{x}^{2}\left(\mathrm{R}^{2}=0.97\right)(\mathrm{P}<0.07) ;$

${ }^{3} \mathrm{Y}=104.159+55.1425 \mathrm{x}-98.4584 \mathrm{x}^{2}\left(\mathrm{R}^{2}=0.96\right)(\mathrm{P}<0.05) ; \mathrm{CV}-$ Variation coefficient.

Source: Elaboration of the authors.

The $\mathrm{pH}$ has influence, directly or indirectly on different meat quality characteristics, the following: color, water retention capacity, tenderness, juiciness and flavor (RÜBENSAM, 2000). PH values to the longissimus dorsi muscle do not show influence from the treatments and remained around the normal standard (Table 7). The values obtained agree with the results obtained by Apple et al. (2002), these authors tested effects from diets with $\mathrm{Mg}(0,1.25$ and $2.5 \%$ of magnesium mica) on swine growing-finishing stage in the same parameters and do not report significant difference. Peeters, Driessen and Geers (2006) also treat swine with $\mathrm{Mg}$ (by water) and do not have significant results for initial and final $\mathrm{pH}$ values. In a contrary way, Apple et al. (2005) found in swine transported during 3 hours and supplemented with magnesium mica a higher initial $\mathrm{pH}$ value that those ones not submitted to transportation independently from consumed diet; however the final $\mathrm{pH}$ measures were not affected by the treatments.

Table 7. Measures (mean \pm standard deviation) of meat starter $\mathrm{pH}$, final $\mathrm{pH}$, percentage of water losses, liquid losses on defrosting process and liquid losses during cooking process from swine treated with different levels of magnesium oxide $(\mathrm{MgO})$ for seven days before slaughter.

\begin{tabular}{cccccc}
\hline $\begin{array}{c}\text { MgO inclusion on } \\
\text { feed (\%) }\end{array}$ & Starter $\mathrm{pH}$ & Final pH & $\begin{array}{c}\text { Percentage water } \\
\text { losses }(\%)\end{array}$ & $\begin{array}{c}\text { Liquid losses } \\
\text { defrosting (\%) }\end{array}$ & $\begin{array}{c}\text { Liquid losses } \\
\text { cooking (\%) }\end{array}$ \\
\hline 0 & $6.40 \pm 0.24$ & $5.67 \pm 0.17$ & $37.22 \pm 3.02$ & $10.77 \pm 2.26$ & $23.64 \pm 3.22$ \\
0.2 & $6.40 \pm 0.24$ & $5.60 \pm 0.12$ & $34.87 \pm 2.97$ & $10.26 \pm 2.15$ & $25.80 \pm 2.91$ \\
0.4 & $6.44 \pm 0.20$ & $5.71 \pm 0.17$ & $35.61 \pm 3.33$ & $8.77 \pm 2.67$ & $21.78 \pm 6.18$ \\
0.6 & $6.25 \pm 0.28$ & $5.63 \pm 0.09$ & $36.65 \pm 2.08$ & $10.30 \pm 3.32$ & $24.41 \pm 3.96$ \\
Regression effect & NS & NS & Quadratic $^{1}$ & Quadratic $^{2}$ & NS \\
\hline CV (\%) & 3.74 & 2.17 & 8.48 & 20.75 & 18.29 \\
\hline
\end{tabular}

${ }^{1} \mathrm{Y}=37.0820-13.2048 \mathrm{x}+21.2031 \mathrm{x}^{2}(\mathrm{R}=0.88)(\mathrm{P}<0.05) ;{ }^{2} \mathrm{Y}=10.9725-9.11458 \mathrm{x}+12.7812 \mathrm{x}^{2}\left(\mathrm{R}^{2}=0.68\right)(\mathrm{P}<0.08) ;$ NS - No significant $(\mathrm{P}>0.05)$; $\mathrm{CV}-$ Variation coefficient.

Source: Elaboration of the authors.

The water retention capacity is a very important characteristic because affect the appearance of meat before cooking, the behavior during the cooking process, the juiciness during the chew process and the technologic yield for preparation of meat products (LAWRIE, 2005). 
The percentage of water losses show a quadratic effect (Table 7), the point of minimum loss was the inclusion level of $0.31 \% \mathrm{MgO}$. D'Souza et al. (1998, 1999), Hamilton et al. (2003) and Lahucky et al. (2004) had verified a reduction in drip losses for longissimus dorsi muscle for swine supplemented with $\mathrm{MgO}$ during a short time period. However, Apple et al. (2000b, 2002, 2005) and Caine et al. (2000) that had supplemented diets with magnesium for longer time periods had observed no differences in the same parameter

For the water losses during the defrosting, there was observed a quadratic effect (Table 7) and the point of minimum loss was for $0.35 \%$ of $\mathrm{MgO}$ inclusion on feed. The water losses during the cooking process had no influence from the treatments (Table 7). This result is according to that reported by Swigert et al. (2004), these authors had tested the influence of magnesium supplementation by water on the meat quality characteristics and palatability attributes of swine meat.

There was no significant differences for the parameters of meat color $\left(\mathrm{L}^{*}, \mathrm{a}^{*}, \mathrm{~b}^{*}\right.$, croma and hue value) (Table 8). The meat color had direct influence from $\mathrm{pH}$ values. Therefore following the results of $\mathrm{pH}$, the color also does not show significant differences between treatments. These results are following the data found by Apple et al. (2000b), that evaluating different magnesium sources influence on lamb muscle quality do not observed significant differences for the color values $\left(\mathrm{L}^{*}, \mathrm{a}^{*} \mathrm{e} \mathrm{b}^{*}\right.$ ), and also for the results of croma and hue value. The results of D'Souza et al. (1999) do not show differences for the luminosity values when testing different magnesium sources on swine feed during five days before the slaughter. However, the improvement of meat color in association with dietetic magnesium supplementation was reported by Hamilton et al. (2003), which have tested different magnesium sources and different supplementation periods for swine before the slaughter. They had observed that animals receiving lower inclusion of $\mathrm{Mg}$ (1.6g Mg/swine/day) had lower values for $\mathrm{L}^{*}$, what means less pale meat when compared with swine from control treatment. Taking in account the data presented can be noted that still exist a lot of controversy around the $\mathrm{Mg}$ action mode and best inclusion level to obtained improvement on meat color.

Table 8. Color meat measures (mean \pm standard deviation) of luminosity $\left(\mathrm{L}^{*}\right)$, red intensity (a*), yellow intensity $\left(b^{*}\right)$, croma $\left(\mathrm{c}^{*}\right)$ e tonality $\left(\mathrm{h}^{\circ}\right)$ for swine treated with Magnesium oxide $(\mathrm{MgO})$ for seven days before slaughter.

\begin{tabular}{cccccc}
\hline $\mathrm{MgO}$ inclusion on feed (\%) & $\mathrm{L}^{*}$ & $\mathrm{a}^{*}$ & $\mathrm{~b}^{*}$ & $\mathrm{c}^{*}$ & $\mathrm{~h}^{\circ}$ \\
\hline 0 & $54.08 \pm 3.47$ & $4.25 \pm 1.05$ & $9.09 \pm 1.09$ & $10.8 \pm 1.09$ & $64.94 \pm 5.99$ \\
0.2 & $53.35 \pm 3.34$ & $4.08 \pm 1.00$ & $8.86 \pm 1,12$ & $9.79 \pm 1.24$ & $65.45 \pm 5.18$ \\
0.4 & $53.04 \pm 3.17$ & $3.80 \pm 1.01$ & $8.46 \pm 1,20$ & $9.30 \pm 1.35$ & $66.12 \pm 5.36$ \\
0.6 & $53.99 \pm 4.06$ & $5.06 \pm 4.30$ & $8.54 \pm 1.21$ & $10.30 \pm 3.42$ & $62.43 \pm 12.38$ \\
Regression effect & $\mathrm{NS}$ & $\mathrm{NS}$ & $\mathrm{NS}$ & $\mathrm{NS}$ & $\mathrm{NS}$ \\
\hline CV (\%) & 5.83 & 55.16 & 12.43 & 20.08 & 12.56 \\
\hline
\end{tabular}

NS - No significant $(\mathrm{P}>0.05) ;{ }^{3} \mathrm{CV}-$ Variation coefficient

Source: Elaboration of the authors.

The shear force value, myofibrillar fragmentation index, lipid oxidation and ether extract are presented on Table 9. These results are similar those found by Schaefer et al. (1993), Apple et al. (2001) and Swigert et al. (2004). At these moments no were found evidences to suggest that magnesium supplementation had effect on post mortem proteolysis and on meat tenderness. 
Table 9. Measures (mean \pm standard deviation) for shear force, myofibrillar fragmentation index, lipid oxidation (TBARS index) and ether extract for meat from swine supplemented with magnesium oxide (MgO) during seven days before slaughter.

\begin{tabular}{ccccc}
\hline $\begin{array}{c}\text { MgO inclusion on } \\
\text { feed (\%) }\end{array}$ & $\begin{array}{c}\text { Shear force } \\
(\mathrm{kgf})\end{array}$ & $\begin{array}{c}\text { Myofibrillar } \\
\text { fragmentation index }\end{array}$ & $\begin{array}{c}\text { TBARS index } \\
(\mathrm{mg} / \mathrm{kg} \text { sample })\end{array}$ & $\begin{array}{c}\text { Ether Extract } \\
(\%)\end{array}$ \\
\hline 0 & $3.57 \pm 0.68$ & $95.15 \pm 10.23$ & $0.266 \pm 0.03$ & $1.15 \pm 0.60$ \\
0.2 & $3.67 \pm 0.69$ & $88.49 \pm 6.39$ & $0.266 \pm 0.03$ & $0.97 \pm 0.59$ \\
0.4 & $3.40 \pm 0.81$ & $99.35 \pm 4.99$ & $0.261 \pm 0.07$ & $0.93 \pm 0.76$ \\
0.6 & $3.50 \pm 0.82$ & $89.20 \pm 6.42$ & $0.262 \pm 0.06$ & $0.84 \pm 0.28$ \\
Regression effect & $\mathrm{NS}$ & $\mathrm{NS}$ & $\mathrm{NS}$ & $\mathrm{NS}$ \\
\hline CV $(\%)$ & 20.20 & 7.69 & 21.20 & 63.19 \\
\hline
\end{tabular}

NS - No significant $(\mathrm{P}>0.05) ; \mathrm{CV}$ - Variation coefficient.

Source: Elaboration of the authors.

The increase of $\mathrm{MgO}$ inclusion level on diet does not change TBARS values. Apple et al. (2001), testing the effect of $\mathrm{Mg}$ supplementation and the storage time on vacuum packaging $(0,4$ and 8 weeks) on swine meat quality, do not found significant effects on TBARS values on the week 0 . These authors report no evidences suggesting $\mathrm{Mg}$ as having antioxidants properties, which this mineral can act as catalyst or still that $\mathrm{Mg}$ have a role as cofactor on muscle lipid oxidation. However, Kanner, German and Kinsella (1987) report the magnesium as having an antioxidant role acting as substitute of manganese on enzyme activation during the process of lipid peroxidation and generation of free radicals.

The ether extract do not show significant differences for levels of $\mathrm{MgO}$ on swine diets. Apple et al. (2000b) testing the effect of $\mathrm{Mg}$ on lamb meat quality observed the reduction on ether extract level and Schaefer et al. (1993) reported no changes on the lipid level on meat was due the dietetic supplementation of this mineral.

The effect of $\mathrm{MgO}$ supplementation at sensorial meat characteristics is showed on Table 10 . There was no significant difference between the treatments; this result is consistent with that on the shear force parameter (Table 9) that reinforces the result observed for tenderness on this panel. On the Table 8 are the water losses data and these values are similar between the treatments $0 \%$ and $0.6 \%$ of $\mathrm{MgO}$ inclusion. These were the treatments used to sensorial analysis panel and this can explain the fact of no significant differences was observed on the juiciness test. These results are supported by Swigert et al. (2004) that testing vitamin D3, vitamin $\mathrm{E}$ and magnesium levels do not found significant differences for the sensorial panel analysis.

Table 10. Measures (mean \pm standard deviation) observed to sensorial meat characteristics from swine supplemented with magnesium oxide $(\mathrm{MgO})$ during seven days before slaughter.

\begin{tabular}{ccccc}
\hline $\begin{array}{c}\text { Inclusion Mgo on } \\
\text { feed }(\%)\end{array}$ & Odor & Tenderness & Juiciness & Overall aceptability \\
\hline 0 & $3.40 \pm 0.70$ & $5.50 \pm 1.43$ & $2.80 \pm 0.92$ & $6.80 \pm 2.44$ \\
0.6 & $3.10 \pm 0.87$ & $4.60 \pm 1.43$ & $2.20 \pm 1.23$ & $6.70 \pm 1.70$ \\
P value & $\mathrm{NS}$ & $\mathrm{NS}$ & $\mathrm{NS}$ & $\mathrm{NS}$ \\
\hline CV $(\%)$ & 24.38 & 28.35 & 43.41 & 31.17 \\
\hline
\end{tabular}

NS - No significant $(\mathrm{P}>0.05)$; $\mathrm{CV}-$ Variation coefficient.

Source: Elaboration of the authors. 


\section{Conclusion}

The inclusion of $0.3 \%$ of $\mathrm{MgO}$ on the diets of swine during 7 days before the slaughter improved the performance, reduced the animal stress on the slaughter and influenced in a positive way carcass characteristics, back fat thickness, the carcass yield and the water retention capacity.

\section{Acknowledgments}

Authors would like to thank Fundação Araucária de Apoio ao Desenvolvimento Científico e Tecnológico do Paraná for the financial support to the Project.

The experiment was approved by the Ethics Committee on Animal experimentation of the Universidade Estadual de Londrina, Londrina, Brazil (N. 115 /2009).

\section{References}

ASSOCIAÇÃO BRASILEIRA DE CRIADORES DE SUÍNOS - ABCS. Métodos brasileiro de classificação de carcaças. $2^{\text {nd }}$ ed. Rio Grande do Sul: Estrela, 1973.

ASSOCIAÇÃO BRASILEIRA DE NORMAS TÉCNICAS - ABNT. NBR 12806: análise sensorial de alimentos e bebidas. Rio de Janeiro: ABNT, 1993.

AMERICAN MEAT SCIENCE ASSOCIATION. Meat evaluation handbook. Savoy: AMSA, 2001, p. 83-116.

APPLE, J. K.; DAVIS, J. R.; RAKES, L. K.; MAXWELL, C. V.; STIVARIUS, M. R.; POHLMAN, F. W. Effects of dietary magnesium and duration of refrigerated storage on the quality of vacuum-packaged, boneless pork loins. Meat Science, Amsterdam, v. 57, n. 1, p. 43-53, jan. 2001.

APPLE, J. K.; KEGLEY, E. B.; MAXWELL JUNIOR, C. V.; RAKES, L. K.; GALLOWAY, D.; WISTUBA, T. J. Effects of dietary magnesium and short-duration transportation on stress response, postmortem muscle metabolism, and meat quality of finishing swine. Journal of Animal Science, Madison, v. 83, n. 7, p. 1633-1645, july 2005.

APPLE, J. K.; MAXWELL, C. V.; STIVARIUS, M. R.; RAKES, L. K.; JOHNSON, Z. B. Effects of dietary magnesium and halothane genotype on performance and carcass traits of growing finishing swine. Livestock
Production Science, Amsterdam, v. 76, n. 1-2, p. 103113, aug. 2002.

APPLE, J. K.; MAXWELL, C. V.; DERODAS, B.; WATSON, H. B.; JOHNSON, Z. B. Effect of magnesium mica on performance and carcass quality of growingfinishing swine. Journal of Animal Science, Madison, v. 78, n. 8, p. 2135-2143, aug. 2000a.

APPLE, J. K.; WATSON, H. B.; COFFEY, K. P.; KEGLEY, E. B.; RAKES, L. K. Comparison of different magnesium sources on lamb muscle quality. Meat Science, Amsterdam, v. 55, n. 4, p. 443-449, aug. 2000 b.

BARBUT, S. Estimates and detection of the PSE problem in young turkey breast meat. Canadian Journal of Animal Science, Sherbrooke, v. 76, p. 455-457, july 1996.

BRASIL. Ministério da Agricultura, Pecuária e Abastecimento. Instrução Normativa $\mathrm{n}^{\circ} 3$, de 17 de janeiro de 2000. Regulamento técnico de métodos de insensibilização para o abate humanitário de animais de açougue. Diário Oficial [da] República Federativa do Brasil, Brasília, 24 jan. 2000. Seção 1, p. 143.

BRIDI, A. M.; SILVA, C. A. Métodos de avaliação da carcaça e da carne suína. $2^{\text {nd }}$ ed. Londrina: Midiograf, 2009. $120 \mathrm{p}$.

CAINE, W. R.; SCHAEFER, A. L.; AALHUS, J. L.; DUGAN, M. E. R. Behaviour, growth performance and pork quality of pigs differing in porcine stress syndrome genotype receiving dietary magnesium aspartate hydrochloride. Canadian Journal of Animal Science, Sherbrooke, v. 80, n. 1, p. 175-182, 2000.

CRACKEL, R. L.; GRAY, I. J.; PEARSON, A. M.; BOOREN, A. M.; BUCKLEY, D. J. Some further observations on the TBA test as an index of lipid oxidation in meats. Food Chemistry, London, v. 28, n. 3, p. 187-196, 1998.

CULLER, R. D.; PARRISH JUNIOR, F. C.; SMITH, G. C.; CROSS, R. Relationship of myofibril fragmentation index to certain chemical, physical and sensory characteristic of bovine longissimus muscle. Journal of Food Science, Chicago, v. 43, n. 4, p. 1177-1180, july 1978.

D'SOUZA, D. N.; WARNER, R. D.; DUNSHEA, F. R.; LEURY, B. J. Comparison of different dietary magnesium supplements on pork quality. Meat Science, Amsterdam, v. 51, n. 3, p. 221-225, mar. 1999.

D'SOUZA, D. N.; WARNER, R. D.; LEURY, B. J.; DUNSHEA, F. R. The effects of dietary magnesium aspartate supplementation on pork quality. Journal of Animal Science, Madison, v. 76, n. 1, p. 104-109, jan. 1998. 
FÁVERO, J. A. Importância do processo de tipificação na melhoria de carcaças de suínos. In: REUNIÃO ANUAL DA SOCIEDADE BRASILEIRA DE ZOOTECNIA, 38., 2001, Piracicaba. Anais... Brasília: Editora da SBZ, 2001, p. 158-163.

FÁVERO, J. A.; GUIDONI, A. L.; BELAVER, C. Predição do índice de valorização de carcaças suínas em função do peso e do percentual de carne. In: CONGRESSO BRASILEIRO DE VETERINÁRIOS ESPECIALISTAS EM SUÍNO, 8., 1997, Concórdia. Anais... Concórdia: EMBRAPA/CNPSA, 1997. p. 405-406.

FINE, K. D.; SANT'ANA, C. A.; FORDTRAN, J. S. Diagnosis of magnesium-induced diarrhea. New England Journal Medicine, Waltham, v. 324, p. 1012-1017, apr. 1991.

GUIDONI, A. L. Melhorias de processos para a tipificação e valorização de carcaças suinas no Brasil. In: CONFERÊNCIA INTERNACIONAL VIRTUAL SOBRE A QUALIDADE DE CARNE SUÍNA, 1., 2000, Concórdia. Anais... Concórdia: EMBRAPA/CNPSA, 2000. p. 221-234.

HAMILTON, D. N.; ELLIS, M.; HEMANN, M. D.; MCKEITH, F. K.; MILLER, K. D.; PURSER, K. W. The impact of longissimus glycolytic potential and shortterm feeding of magnesium sulfate heptahydrate prior to slaughter on carcass characteristics and pork quality. Journal of Animal Science, Madison, v. 80, n. 6, p. 15861592, june 2002.

HAMILTON, D. N.; ELLIS, M.; MCKEITH, F. K.; EGGERT, J. M. Effect of level, source, and time of feeding prior to slaughter of supplementary dietary magnesium on pork quality. Meat Science, Amsterdam, v. 65 , n. 2 , p. $853-857$, oct. 2003.

HEATON, F. W. Magnesium requirement for enzymes and hormones. Biochemical Society Transactions, London, v. 1, p. 67-70, 1973.

INSTITUTO ADOLFO LUTZ - IAL. Normas analíticas do instituto Adolfo Lutz: métodos físicos e químicos para análise de alimentos. $3^{\text {rd }}$ ed. São Paulo: IMESP, 1985. 21 p.

KANNER, J.; GERMAN, J. B.; KINSELLA, J. E. Initiation of lipid peroxidation in biological systems. Critical Reviews in Food Science and Nutrition, Beltsville, v. 25, n. 4, p. 317-364, 1987.

LAHUCKY, R.; NÜRNBERG, K.; KÜCHENMEISTER, U.; BAHELKA, I.; MOJTO, J.; NÜRNBERG, G.; ENDER, K. The effect of dietary magnesium oxide supplementation on fatty acid composition, antioxidative capacity and meat quality of heterozygous and normal malignant hyperthermia (MH) pigs. Archiv Tierzucht
Dummerstorf, v. 47, n. 2, p. 183-191, 2004.

LAWRIE, R. A. Ciência da carne. $6^{\text {th }}$ ed. Porto Alegre: Artmed, 2005. 384 p.

MINOLTA. Precise color communication: color control from perception to instrumentation. Japan: Minolta Co. Ltd, 1998. 19 p.

NATIONAL RESEARCH COUNCIL - NRC. Nutrient requirement of swine. $10^{\text {th }}$ ed. Washington, DC: National Academy Press, 1998. 189 p.

OLIVEIRA, D. E. Minerais: funções, deficiências, toxidez e outros aspectos da suplementação. Rio Claro: Agroceres, 2005. (Material técnico sobre minerais).

PEETERS, E.; DRIESSEN, B.; GEERS, R. Influence of supplemental magnesium, tryptophan, vitamin C, vitamin $\mathrm{E}$, and herbs on stress responses and pork quality. Journal of Animal Science, Madison, v. 84, n. 7, p. 1827 1838 , july 2006.

RÜBENSAM, J. M. Transformações postmortem e qualidade da carne suína. In: CONFERÊNCIA INTERNACIONAL VIRTUAL SOBREAQUALIDADE DE CARNE SUÍNA, 2000, 1., Concórdia. Anais... Concórdia: EMBRAPA/CNPSA, 2000. p. 89-99.

SCHAEFER, A. L.; MURRAY, A. C.; TONG, A. K. W.; JONES, S. D. M.; SATHER, A. P. The effect of ante mortem electrolyte therapy on animal physiology and meat quality in pigs segregating at the halothane gene. Canadian Journal of Animal Science, Sherbrooke, v. 73, n. 2, p. 231-240, 1993.

SWIGERT, K. S.; MCKEITH, F. K.; CARR, T. C.; BREWER, M. S.; CULBERTSON, M. Effects of dietary vitamin D3, vitamin E, and magnesium supplementation on pork quality. Meat Science, Amsterdam, v. 67, n. 1, p .81-86, may 2004.

TARLADGIS, B. G.; PEARSON, A. M.; DUGAN JUNIOR, L. R. Chemistry of 2- thiobarbituric test for determination of oxidative rancidity in foods. II. Formation of the TBA- malonaldehyde complex without acid-heat treatment. Journal of Food Science and Agriculture, London, v. 15, n. 9, p. 602-607, sept. 1964.

UNIVERSIDADE FEDERAL DE VIÇOSA - UFV. Sistema de análises estatísticas e genéticas SAEG. (Versão 7.1). Viçosa: Universidade Federal de Viçosa, 1997.

WHIPPLE, G.; KOOHMARAIE, M.; DIKEMAN, M. E. Evaluation of attributes that affect longissimus muscle tenderness in Bos Taurus and Bos indicus cattle. Journal of Animal Science, Madison, v. 68, n. 9, p. 2716-2728, sept. 1990. 
